International Journal of Current Advanced Research

ISSN: O: 2319-6475, ISSN: P: 2319 - 6505, Impact Factor: SJIF: 5.995

Available Online at www.journalijcar.org

Volume 6; Issue 4; April 2017; Page No. 3281-3283

DOI: http://dx.doi.org/10.24327/ijcar.2017.3283.0248

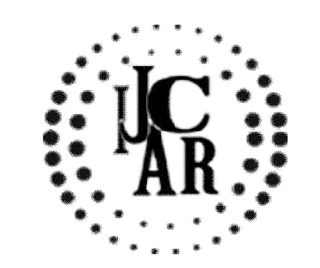

Research Article

\title{
AWARENESS ON TOOTH SENSITIVITY AND EXCESS CONSUMPTION OF AERATED SOFT DRINKS - A SURVEY
}

\author{
Ashwin Kumar S.P
}

Saveetha Dental College and Hospitals, P.H. Road, Chennai 77

\begin{tabular}{l}
\hline A R T I C L E I N F O \\
\hline Article History: \\
Received $20^{\text {th }}$ January, 2017 \\
Received in revised form $10^{\text {th }}$ February, 2017 \\
Accepted $2^{\text {nd }}$ March, 2017 \\
Published online $28^{\text {th }}$ April, 2017 \\
\hline
\end{tabular}

Key words:

Excess Consumption, Aerated Soft Drinks

\begin{abstract}
A B S T R A C T
Aim: To find the relation between soft drinks or aerated drinks that causes sensitivity. Background: Soft drinks contain a lot of sugar. The decay of the sugar particles in the soft drink causes sensitivity first and then in further stages the erosion of enamel and tooth decay can also take place. Over time, a hole develops which is called a cavity. The sugars in the soft drinks interact with bacteria in the mouth to form acid. This acid attacks the teeth. Both regular and sugar-free sodas also contain their own acids, and these attack the teeth too. Soft drinks have phosphoric acid and citric acid, which wear away the enamel of the tooth and can cause sensitivity.

Reason: To create awareness among the public about the hazards of soft drinks.

Results: According to the survey taken most of the people are aware that soft drinks are harmful to them and it also causes tooth sensitivity due to the erosion of enamel.
\end{abstract}

Copyright $₫ 2017$ Ashwin Kumar S.P. This is an open access article distributed under the Creative Commons Attribution License, which permits unrestricted use, distribution, and reproduction in any medium, provided the original work is properly cited.

\section{INTRODUCTION}

A soft drink (see terminology for other names) is a drink that typically contains carbonated water, a sweetener, and a natural or artificial flavoring. The sweetener may be sugar, high-fructose corn syrup, fruit juice, sugar substitutes (in the case of diet drinks), or some combination of these. Soft drinks may also contain caffeine, colorings, preservatives, and other ingredients. Soft drinks are called "soft" in contrast to "hard drinks" (alcoholic beverages). Small amounts of alcohol may be present in a soft drink, but the alcohol content must be less than $0.5 \%$ of the total volume [1][2] if the drink is to be considered non-alcoholic.[3] Fruit punch, tea, and other such non-alcoholic. Beverages are technically soft drinks by this definition but are not generally referred to as such. Soft drinks are mixed with other ingredients in several contexts. In Western countries, in bars and other places where alcohol is served (e.g., airplanes, restaurants and nightclubs) many mixed drinks are made by blending a soft drink with hard liquor and serving the drink over ice. One well-known example is the rum and coke, which may also contain lime juice. The over-consumption of sugar-sweetened soft drinks is associated with obesity,[4][5][6]type 2 diabetes,[7] dental caries, and low nutrient levels.[5]Experimental studies tend to support a causal role for sugar-sweetened soft drinks in these ailments,[4][5] though this is challenged by other researchers.[8][9][10]"Sugar-sweetened" includes drinks that use high-fructose corn syrup, as well as those using sucrose.

*Corresponding author: Ashwin Kumar S.P Saveetha Dental College and Hospitals, P.H. Road, Chennai 77
Many soft drinks contain ingredients that are themselves sources of concern: caffeine is linked to anxiety and sleep disruption when consumed in excess, [11] and some critics question the health effects of added sugars and artificial sweeteners. [12] Sodium benzoate has been investigated by researchers at University of Sheffield [13] as a possible cause of DNA damage and hyperactivity. Other substances have negative health effects, but are present in such small quantities that they are unlikely to pose any substantial health risk provided that the beverages are consumed only in moderation. Most soft drinks contain high concentrations of simple carbohydrates: glucose, fructose, sucrose and other simple sugars. If oral bacteria ferment carbohydrates and produce acids that may dissolve tooth enamel and induce dental decay, then sweetened drinks may increase the risk of dental caries. The risk would be greater if the frequency of consumption is high. [14] A large number of soda pops are acidic as are many fruits, sauces and other foods. Drinking acidic drinks over a long period and continuous sipping may erode the tooth enamel. A 2007 study determined that some flavoured sparkling waters are as erosive or more so that orange juice. [15]

Using a drinking straw is often advised by dentists as the drink does not come into as much contact with the teeth. It has also been suggested that brushing teeth right after drinking soft drinks should be avoided as this can result in additional erosion to the teeth due to the presence of acid. [16] Tooth sensitivity is a common dental problem that involves discomfort or pain in teeth when encountering certain substances and temperatures. At least 40 million adults suffer from sensitive teeth in the United States, according to the 


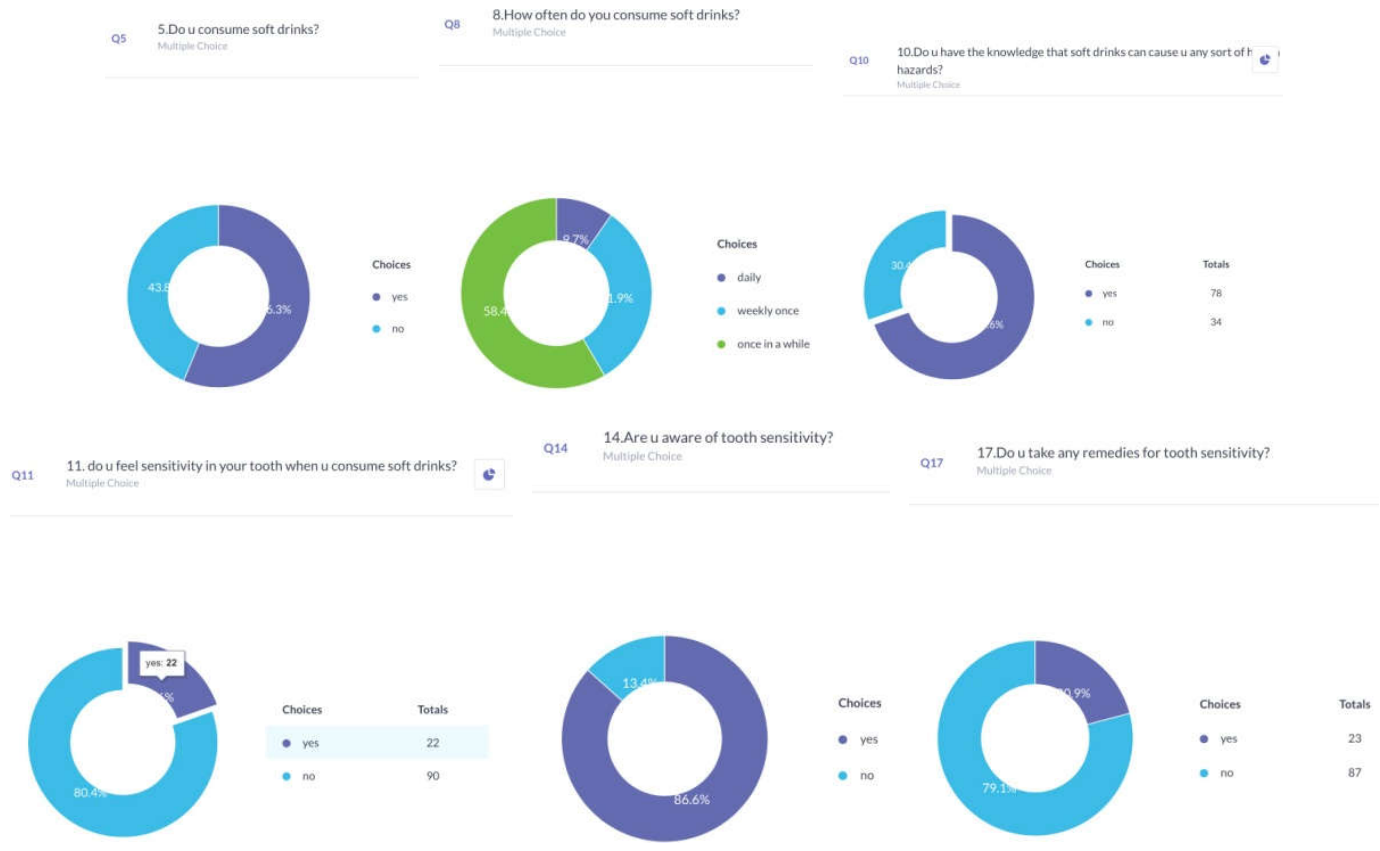

Academy of General Dentistry. The pain is often sharp and sudden, but it is temporary. According to the Cleveland Clinic, the pain may shoot into the tooth's nerve endings. Fortunately, sensitive teeth can be treated and the condition can improve. Tooth sensitivity is a common dental problem that involves discomfort or pain in teeth when encountering certain substances and temperatures. At least 40 million adults suffer from sensitive teeth in the United States, according to the Academy of General Dentistry. The pain is often sharp and sudden, but it is temporary. According to the Cleveland Clinic, the pain may shoot into the tooth's nerve endings. Fortunately, sensitive teeth can be treated and the condition can improve.

\section{MATERIALS AND METHODS}

Questionnaire based on the survey was conducted through a link created using survey planet software.100 students were involved in the survey.

\section{RESULTS \\ DISCUSSION}

According to the above results most of the people are clear that soft drinks are hazardous to life and they avoid drinking. But only few are aware that they may cause sensitivity to the tooth and it may also erode the enamel.

\section{CONCLUSION}

From this survey it can be concluded that $90 \%$ of the population are aware that drinking soft drinks causes health hazards mainly like tooth sensitivity. This survey may help in creating awareness about sensitivity due to soft drinks

\section{Reference}

1. "Electronic Code of Federal Regulations". United States Government. Retrieved 25 February 2011.

2. "What Is Meant By Alcohol-Free?: The Alcohol-Free Shop". Alcoholfree.co.uk. 2012-01-08. Retrieved 201303-26.
3. Bangor Daily News, April 8, 2010. http://www.bangordailynews.com/detail/126224.html

4. Malik VS, Schulze MB, Hu FB (2006). "Intake of sugar-sweetened beverages and weight gain: a systematic review". The American Journal of Clinical Nutrition. 84 (2): 274-88.

5. Vartanian LR, Schwartz MB, Brownell KD (2007). "Effects of soft drink consumption on nutrition and health: a systematic review and meta-analysis". American Journal of Public Health. 97

6. Woodward-Lopez G, Kao J, Ritchie L (2011). "To what extent have sweetened beverages contributed to the obesity epidemic?". Public Health Nutrition. 14 (3): 499-509.

7. Imamura F, O'Connor L, Ye Z, Mursu J, Hayashino Y, Bhupathiraju SN, Forouhi NG (2015). "Consumption of sugar sweetened beverages, artificially sweetened beverages, and fruit juice and incidence of type 2 diabetes: systematic review, meta-analysis, and estimation of population attributable fraction"

8. Gibson S (2008). "Sugar-sweetened soft drinks and obesity: a systematic review of the evidence from observational studies and interventions". Nutrition Research Reviews. 21 (2): 134-47.

9. Wolff E, Dansinger ML (2008). "Soft drinks and weight gain: how strong is the link?". Medscape Journal of Medicine. 10 (8): 189.

10. Trumbo PR, Rivers CR (2014). "Systematic review of the evidence for an association between sugarsweetened beverage consumption and risk of obesity". Nutrition Reviews. 72 (9): 566-74

11. BBC Fizzy drinks 'affect children's sleep'

12. David B. Samadi. "The sweeter side: Benefits and risks of artificial sweeteners". Fox News.

13. Martin Hickman Caution: Some soft drinks may seriously harm your health at the Wayback Machine (archived January 15, 2008) The Independent on Sunday 27 May 2007

14. Marshall TA, Levy SM, Broffitt B, Warren JJ, Eichenberger-Gilmore JM, Burns TL, Stumbo PJ 
(2003). "Dental caries and beverage consumption in young children". Pediatrics. 112 (3 Pt 1): e184-91

15. Brown, Catronia J.; Smith, Gay; Shaw, Linda; Parry, Jason; Smith, Anthony J. (March 2007). "The erosive potential of flavoured sparkling water drinks". International Journal of Paediatric Dentistry. British Paedodontic Society and the International Association of Dentistry for Children. 17 (2): 86-91.
16. Bassiouny MA, Yang J (2005). "Influence of drinking patterns of carbonated beverages on dental erosion". General Dentistry. 53 (3): 205-10.

\section{How to cite this article:}

Ashwin Kumar S.P (2017) ' Awareness On Tooth Sensitivity And Excess Consumption Of Aerated Soft Drinks - A Survey', International Journal of Current Advanced Research, 06(04), pp. 3281-3283.

DOI: http://dx.doi.org/10.24327/ijcar.2017.3283.0248 